\title{
Oferecer uma flor, oferecer sua philia
}

Nikolina Ke[ ${ }^{[1]}$

\section{Resumo}

Existe, na cerâmica ática dos séculos VI e V a. C., certo número de imagens nas quais o gesto de oferecer uma flor a alguém se apresenta como uma maneira de saudá-lo, além de expressar sua estima, seu reconhecimento e seu afeto. Objeto de prazer tanto visual, como olfativo e tátil, a flor é um dom que seduz, capaz de atar ou de reforçar os laços de amizade. Assim, em cenas de partida, de encontro, de reencontros e até de reconciliação, a presença discreta da flor remete às noções gregas de philia (amizade) e de charis (amor) em todas as suas declinações: charme, generosidade, prazer. Palavras-chave: flor; charis; philia.

\section{Ofrecer una flor, ofrecer su philia}

\section{Resumen}

Existen, en la cerámica ática de los siglos Vy VI a. C., algunas imágenes en las que ofrecer una flor a alguien se presenta como una forma de saludarlo, además de expresar su estima, su reconocimiento y su afecto. Objeto de un placer a la vez visual, olfativo y táctil, la flor es algo que alegra y es capaz de iniciar o reforzar lazos de amistad. Asimismo, en escenas de partida, de encuentro, de reencuentros o hasta mismo de reconciliación, la discreta presencia de la flor remite a las nociones griegas de philia (amistad) y de charis (amor), en todas sus declinaciones: encanto, generosidad, placer.

Palabras claves: flor; charis; philia.

\section{To offer a flower, to offer your philia}

\section{Abstract}

There is a rather small set of images on attic vases dating from the sixth and fifth century BCE, where the gesture of offering a flower to someone is as a way to salute while expressing his/her esteem, gratitude and affection. As an object of visual, olfactory and tactile pleasure, the flower is a gift that delights, capable of establishing or strengthening relations of friendship. Thus, within scenes of departure, meeting, reunion and even reconciliation, the discreet presence of the flower conveys the Greek notions of philia (friendship) and charis in all its declinations: charm, generosity, pleasure.

\section{Keywords: flower; philia; charis}

\section{Offrir une fleur, offrir sa philia}

\section{Résumé}

Il existe dans la céramique attique du Vle et du Ve siècle av. J.-C., un certain nombre d'images où le geste d'offrir une fleur à l'autre se présente comme un moyen de le saluer tout en lui exprimant son estime, sa reconnaissance et son affection. Objet de plaisir à la fois visuel, olfactif et tactile, la fleur est un don qui ravit, capable de nouer ou de renforcer des rapports d'amitié. Ainsi, à l'intérieur des scènes de départ, de rencontre, de retrouvailles et même de réconciliation, la présence discrète de la fleur véhicule-t-elle les notions grecques de philia (amitié) et de charis dans toutes ses déclinaisons: charme, générosité, plaisir.

Mots-clés: fleur; charis; philia. 
$\mathrm{E}$ m uma das faces de sua célebre ânfora, hoje no Vaticano (figura 1), Exéquias representa uma cena familiar: Leda e Tíndaro observam o retorno de Castor e Pólux. ${ }^{2}$ Pais e filhos carregam coroas vegetais, sinal da solenidade do momento. Cada gesto esboçado pelas figuras adiciona toques de intimidade e afeto à cena: Pólux se distrai acariciando seu cachorro, que se joga sobre ele, Tíndaro afaga a cabeça de seu cavalo, Kylaros, enquanto Leda levanta dois ramos com a mão direita e estende uma flor para Castor com a outra, como forma de saudação. ${ }^{3} \mathrm{O}$ rapaz, virando-se para a direita, na direção de Tíndaro, vira a cabeça, atraído pelo gesto de sua mãe para ele. A flor, símbolo da acolhida, assim como os ramos, sinal de celebração, ${ }^{4}$ fica à meia distância entre os dois rostos, de modo que ela chama a atenção do espectador para a troca de olhares e, muito provavelmente, de palavras entre mãe e filho: ela é a marca da relação mãe-filho, de sua philia parental. ${ }^{5}$

\section{Tive a oportunidade de mostrar ainda que na cerâmica ática a flor se apresenta como símbolo da noção polivalente de charis}

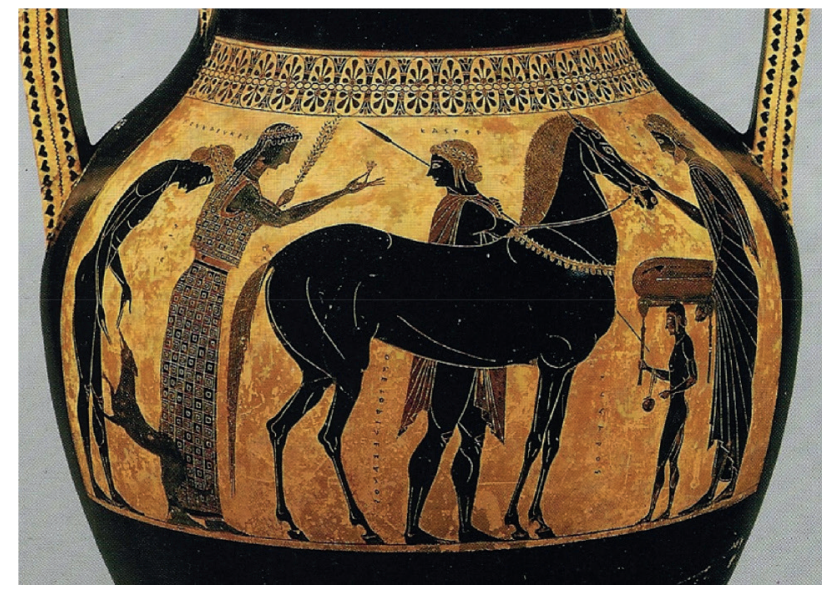

Figura 1

\footnotetext{
2Vaticano, Museu Gregoriano Etrusco Vaticano 344; 540-530 a.C.; ABV 145.13, 672.3, 686; Para 60; Add² 40; BArch 310395. Para uma análise completa e um resumo crítico das inúmeras interpretações que a cena já inspirou, ver Mackay (2010, p.339-348).

${ }^{3}$ Hermary (1978, p.51-76 e em particular p.69) identifica as folhas como ramos de mirta e a flor como uma rosa, os dois vegetais supostamente como "símbolos de imortalidade". Fora o fato de que nada, nem nos textos, nem nas imagens, prova que a mirta e a rosa sejam símbolos de imortalidade, nos vasos áticos, plantas, folhagens e sobretudo as flores são, em regra geral, muito estilizados e abstratos para permitirem uma identificação botânica precisa. Existem, contudo, algumas exceções, como a palmeira, a hera, a videira, às vezes o louro e a oliveira, que são plantas estritamente associadas a divindades e devem ser identificáveis. Sobre a dificuldade de identificar os elementos vegetais de nossa imagem, ver Mackay (2010, p.345).

${ }^{4}$ Ofecer os ramos é uma forma de celebrar as qualidades não somente atléticas, mas relativas à caça e à guerra de dois gêmeos: sobre essas qualidades, ver Hermary (1986, p.567-8).

5Sobre a noção de philia, ver nota 8.
} 
Tive a oportunidade de mostrar ainda que na cerâmica ática a flor se apresenta como símbolo da noção polivalente de charis, ${ }^{6}$ pelo modo como ela se incorpora às três Cárites hesiódicas, Aglaia, Tália e Eufrosina. Elas evocam, respectivamente, a radiação de uma bela aparência, a abundância que remete à generosidade e às despesas e, finalmente, à alegria festiva. ${ }^{7}$ Mais frequentemente, a flor surge como objeto de prazer, tanto visual quanto olfativo e tátil, materializando a graça física, a beleza juvenil e resplandescente, em pleno desenvolvimento (anthos hèbès), bem como o bom odor, componente essencial da atração física. De fato, nos vasos áticos, inúmeras figuras divinas ou mortais seguram flores, fora de toda a tensão e intenção de movimento, como se elas fossem parte integrante de seus corpos: imóveis e hieráticas, as figuras se entregam ao olhar do espectador, em toda a sua beleza e elegância demonstradas e realçadas pelas próprias flores. Outras vezes, como na ânfora de Exéquias, os pintores colocam as flores no centro de uma dinâmica alcançada pelos gestos de saudação ou de oferenda, mais ou menos discretos: tiradas de sua inércia de simples movimentos corporais, elas se apresentam como mediadoras e suportes para uma comunicação, de uma troca entre duas ou mais pessoas. Elas têm dons de escolha, seu charme e perfume são capazes de alegrar e de invocar uma reação favorável de volta. Em outras palavras, as flores podem materializar outra forma de charis, considerada menos como uma qualidade exterior do que como uma disposição interior, manifestada por meio do gesto do dom: essa charis é encarnada por Thalia. Ora, o gesto do dom é, a princípio, um gesto que gera alegria e prazer, afetos que são encarnados por Eufrosina..$^{8}$ Por exemplo, as três declinações da charis encontram-se reunidas no gesto do dom floral.

Mais precisamente, as flores como dons aparecem nas três categorias de cenas: primeiramente, nas cenas de cortejo erótico, nas quais se apresentam como forma de sedução e persuasão. Depois, nas cenas de oferenda cultual, em que elas devem criar e alimentar a ligação entre mortais e deuses. Finalmente, nas cenas partida, de encontro ou de reencontros, momentos solenes, nos quais o gesto de dar uma flor ao outro é uma maneira de saudá-lo, expressando sua estima e seu reconhecimento. Igualmente, esse mesmo gesto pode exprimir o desejo de estabelecer ou de reforçar os elos de philotês ou philia, ${ }^{9}$ bem como o prazer de estar ou de se encontrar com algum ente querido. É essa última categoria de cenas de partida, de encontro ou de reencontros que chamará nossa atenção.

\footnotetext{
${ }^{6} \mathrm{~A}$ flor, como indicador da noção polivalente de charis na cerâmica ática, é o tema central de minha tese de doutorado. Permito-me, ainda, fazer referência aos meus três artigos sobre o assunto, datados de 2007; 2008, p.197-203; e 2015 (no prelo).

7Retomo aqui a análise de Daniel Saintillan (2003, p.541-64) sobre os nomes de Cárites hesiódicas. Inúmeros são os estudos sobre a noção de charis, mas seria impossível citá-los todos. Remeto-me, ainda, a título indicativo, ao estudo de MacLachlan (1993), e ao de Azoulay (2004), com bibliografia muito rica sobre as diferentes constelações do termo.

${ }^{8}$ Sobre o dom e seu campo semântico na antiguidade grega, ver Benveniste (1982, p.315-9 e 1969, p.81-82). Ver também Scheid (1994); Brillante (1998, p.7-34 e especialmente p.23) e Vidal (1991, p.30-47).

9 Sobre philia como ligação afetiva, hospitalidade e união, ver Benveniste (1969, p. 335-53); Taillardat (1982. p.1-14); Alaux (1995, p.199 sq).
} 
Vimos que, na ânfora de Exéquias, a flor que Leda oferece a Castor na ocasião de seu retorno surge como símbolo de celebração, de receptividade e de philia entre a mãe e seu filho. Encontramos o mesmo gesto nas cenas de partida. Em um dos lados de um vaso de Oltos (figura 2), uma jovem mulher oferece uma flor a um guerreiro, que se prepara para partir em companhia de outros guerreiros, entre os quais está Ajax em pessoa. ${ }^{10}$ Se a mulher é a mãe do guerreiro, o que não é de todo improvável, pela presença de um homem idoso um pouco mais longe, a função da flor é de despedida, reforçando a relação mãe-filho. Se, ao contrário, o homem for seu marido, o que parece mais provável, a flor poderia desta vez demonstrar a despedida e simbolizar sua philia conjugal. De qualquer modo, o gesto da mulher ecoa o gesto do idoso, e os dois demonstram certa afetividade, em um momento ao mesmo tempo solene e emocional, reforçado pela partida para o campo de batalha.

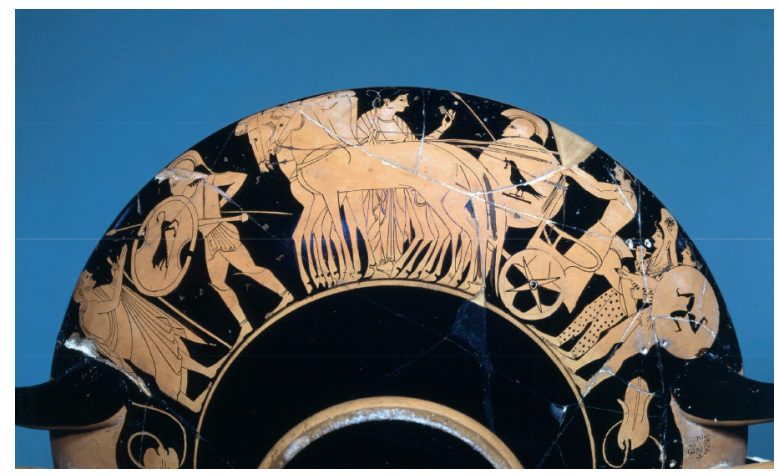

Figura 2

Em outros casos, a flor registra a philia fraternal, relação que só se pode identificar em um contexto mitológico: assim, em uma cratera, Apolo saúda sua irmã Ártemis com uma flor ao subir em sua quadriga. ${ }^{11}$ Sobre uma hydria próxima do Pintor de Príamo, o próprio Apolo sobe em uma quadriga observado por sua mãe, Léto. Ártemis segura sua cítara, enquanto Hermes estende uma flor em sinal de adeus (figura 3 ). ${ }^{12}$ Essa imagem de âmbito familiar é, portanto, marcada por dois elementos de conotação festiva e fontes de prazer e encantamento: a cítara, instrumento musical, e a flor, símbolo visual e olfativo, que são ambos fontes de prazer e encantamento.

\footnotetext{
10Londres, British Museum E 16; 520-510 a.C.; ARV² 61.75, 1599.14; Add² 165; BArch 200511. "Atenas, Museu de Ágora P9275; 500-490 a.C.; BArch 7833; LIMC II, "Artemis", n. 1210, pl. 544. Mesmo que a figura feminina não seja mencionada, a presença de Apolo, das duas palmeiras e da gazela nos fazem pensar em Artemis. Uma cena semelhante aparece sobre uma "escharis" de barro, em que Apolo oferece uma flor a uma deusa ao subir em uma quadriga, na presença de uma segunda deusa e de Hermes: Eleusis, Musée Archéologique 468; Pintor da fonte de Madrid; ABV 335.2; BArch 301823.

12Paris, Musée du Louvre F297; 520-510 a.C:; ABV 333.1; Add² 91; BArCh 301808. Os nomes estão inscritos no genitivo.
} 


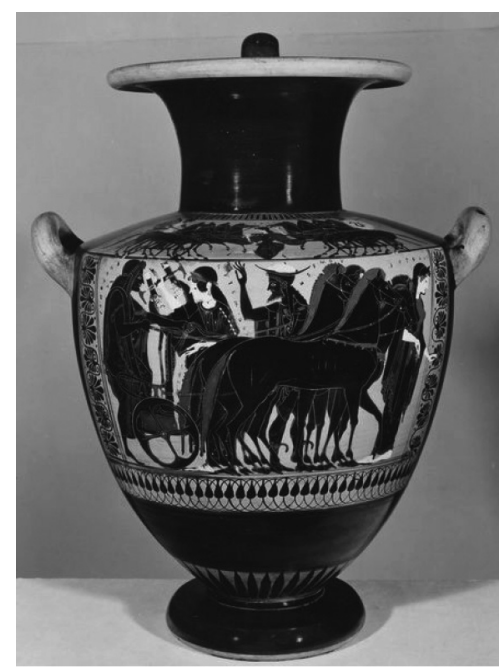

Figura 3

Algumas palavras sobre Hermes: ele é o deus que porta o caduceu da opu-

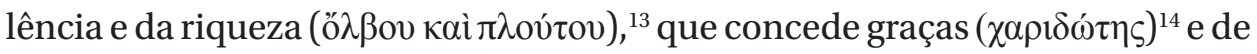
dons resplandescentes $(\dot{\alpha} \gamma \lambda \alpha \dot{\alpha} \delta \tilde{\omega} \rho \alpha){ }^{15}$ fundador da troca de bens $(\dot{\varepsilon} \pi \alpha \mu o i ́ \beta \mu \alpha$ $\varepsilon \rho \gamma \alpha) .{ }^{16}$ Ele se alegrava com o canto suave da lira ${ }^{17}$ e suas palavras doces, enquanto se divertia acompanhando as Cárites, as Horas, as Musas e as Ninfas em seus passeios. ${ }^{18}$ Com traços de um jovem rapaz, sua primeira barba marca

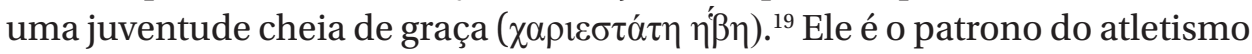
e o protetor da juventude. Incontestavelmente, as ligações de Hermes com a charis são muito estreitas; por isso, de todas as divindades masculinas, ele é o mais frequentemente representado com uma flor na mão: o vaso de Oltos em Tarquínia, no qual o deus segura de forma ostensiva um lindo botão floral, é sem dúvida o exemplo mais conhecido. ${ }^{20} \mathrm{~A}$ charis marca igualmente as relações tanto íntimas quanto complexas entre Hermes e Apolo, seladas por uma série de trocas reconciliadoras. Se Apolo alegra os deuses com sua música, é graças à mètis, astúcia, de Hermes. Ávido por honrarias, timai, o filho de Maïa, utilizou duas declinações da charis, euphrosynè e aglaïa, e a visibilidade sedutora de sua lira/cítara obtida por Apolo, para extrair dele como contra-dom o kûdos, a glória. ${ }^{21}$ É provável que o gesto de Hermes na hydria do Pintor de Príamo seja um eco distante dessa série de trocas entre os dois irmãos.

\footnotetext{
${ }^{13}$ Hino homérico a Hermes, I, 529.

${ }^{14}$ Hino homérico a Hermes, II, 12.

${ }^{15}$ Hino homérico a Hermes, I, 462.

${ }^{16}$ Hino homérico a Hermes, I, 516-7. Sobre a relação do deus com a prática da troca, ver Kahn, Laurence, 1978, p.119 sq. e mais recentemente Jaillard, Dominique (2007, p.91-95).

${ }^{17}$ Hino homérico a Hermes, I, 455, 492-5.

18Sobre as representações de Hermes acompanhado de Cárites ou de Ninfas, ver LIMC V, S. v. "Hermes", p. 317-8.

${ }^{19}$ Odisseia, X, 278-9.

${ }^{20}$ Tarquinia, Museo Nazionale R66848; 510-500 a.C.; ARV2 60,66; Para 327; Add2 81; BArch 200502.

${ }^{21}$ Hino homérico a Hermes, 449 et 476-7.
} 
Em uma ânfora do Grupo de Léagros (figura 4), ${ }^{22}$ Hermes estende uma flor para seu outro meio-irmão, Dionysos. Cercado de videiras, este está de pé entre duas figuras femininas sentadas, enquanto, mais longe, um sátiro faz um gesto de surpresa. O dom floral com o qual Hermes saúda Dionysos, difícil de distinguir entre a folhagem e os cachos da videira, faz alusão ao dom que este último oferece à humanidade; o vinho contido no cântaro e também na ânfora, suporte dessa imagem. Hermes, "conviva de festins", ${ }^{23}$ se apropria com frequência dos atributos canônicos de Dionysos; ${ }^{24}$ é um verdadeiro bon vivant, e a flor em sua mão traduz perfeitamente essa alegria de viver. ${ }^{25}$

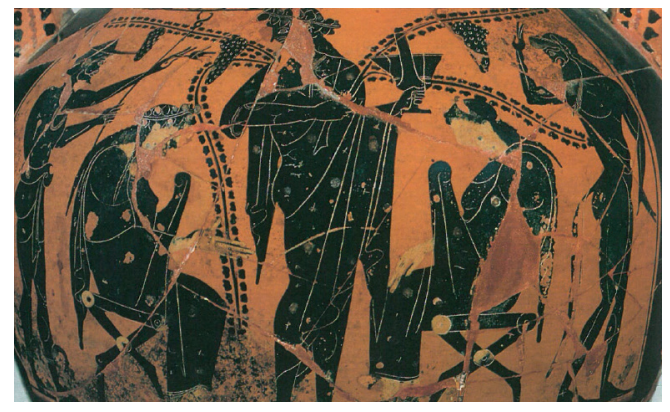

Figura 4

Mais que relações familiares, a flor marca as ligações baseadas na estima e no reconhecimento recíprocos. Sobre uma hydria do Pintor de Achéloos (figura 5), ${ }^{26}$ encontramos Hermes em seu papel de guia, em grego, proegetès, seguido de uma mulher empunhando tochas, de um carro e de um homem de barba. O deus Hermes vem ao encontro de um centauro, provavelmente Chiron, e o saúda com uma flor; seria possível dizer até que o deus insiste que o centauro respire seu perfume suave, já que a flor se aproxima muito de seu rosto. Essa imagem insólita lembra muito a iconografia da entrega de Achiles criança a Chiron, exceto que aqui não há uma criança. ${ }^{27} \mathrm{O}$ fato de todos os personagens serem coroados e de que o centauro traz dois ramos vegetais na sua mão direita cria um ambiente de celebração solene. A flor, símbolo do reconhecimento desse bom e sábio centauro, «educador de heróis e dono de uma genealogia principesca», ${ }^{28}$ só reforça essa ambiência.

\footnotetext{
${ }^{22}$ Orvieto, Museo Civico, Coll. Faina, 186; 520-510 a.C.; ABV 368.98, 389; Para 170.2; Add² 98; BArch 302093.

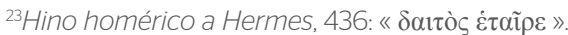

${ }^{24}$ Ver stamnos do Pintor de Berlin à Paris, Louvre CA944; ARV2 207.142, 1633; Add2 194; BArch 201961.

${ }^{25} \mathrm{~A}$ oferta e a troca de dons eram consubstanciais à natureza do deus. É difícil fazer uma distinção entre a flor/atributo do deus e a flor/dom.

${ }^{26}$ Berlin, Antikensammlung F1900; 520-500 a.C.; ABV 385.27; Add² 102; BArch 302872.

${ }^{27}$ De acordo com o Archives Beazley online, o personagem com a flor é Pélée, o que nos parece estranho, já que suas botas são ao mesmo tempo típicas de Hermes e raras no costume cinegético. Além disso, o vemos em vestes de deus, liderando um cortejo e saudando com uma flor na mão.

${ }^{28}$ Ver Schnapp (1997, p.439).
} 


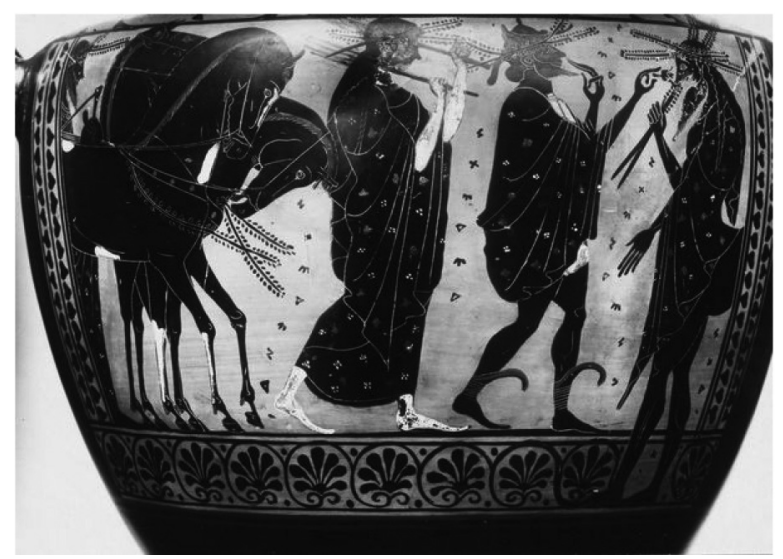

Figura 5

Finalmente, na hydria do Pintor de Príamo (figura 6), ${ }^{29}$ é o próprio Hermes que aparece como destinatário de um dom floral. Seguido de nove figuras femininas representadas de forma indiferente, e de Dionysos, ele vira a cabeça, interpelado pelo gesto da oferta floral que a figura feminina no começo do cortejo lança sobre ele. A flor, que, com frequência, na cerâmica ática de figuras negras, serve de peça corporal para as divindades com identidade imprecisa como as Musas ou as Ninfas, aparece aqui em um gesto que expressa o reconhecimento e o compromisso que o cortejo sente para com seu guia.

\section{Mais que relações familiares, a flor marca as ligações baseadas na estima e no reconhecimento recíprocos}

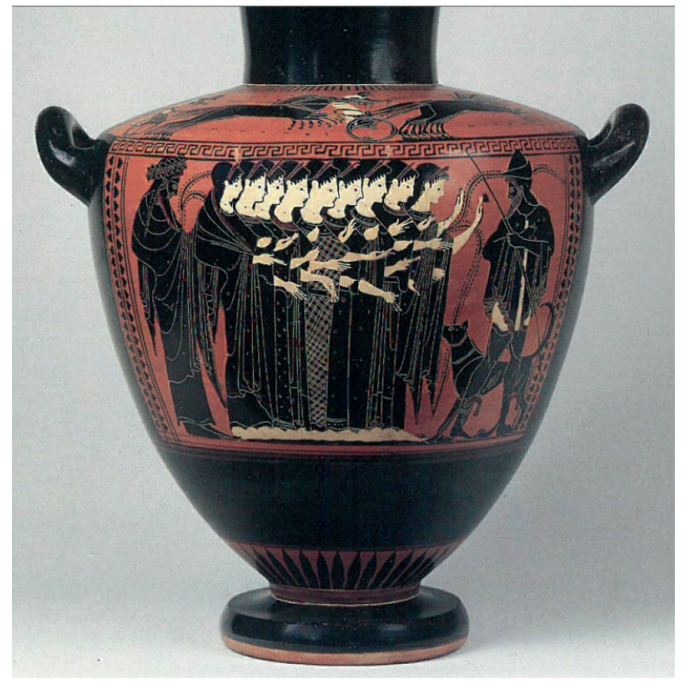

Figura 6 
Em uma situação muito mais festiva e alegre, vemos, sobre a taça do Pintor de Chiusi (figura 7), ${ }^{30}$ Dionysos sentir o perfume da flor que uma mênade lhe oferece. Esse gesto é um tipo de convite para que o deus celebre a grande alegria que ele inspira em suas acólitas, mênades e sátiros, e que se reflete bem, tanto no interior quanto no exterior da taça: os ramos e os cachos da videira invadem a imagem na superfície do vaso, as posturas dançantes e os gestos agitados da thiase, o traje poikilia, a policromia e a pletora dos detalhes finamente representados criam um ambiente exuberante, bem adequado ao estilo dionisíaco.

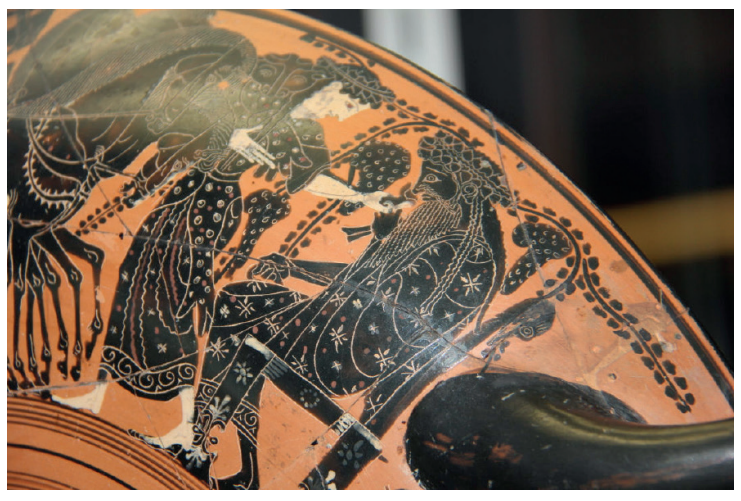

Figura 7

É ao mesmo tempo como dom de acolhida e símbolo de reconhecimento que Athená oferece a seu protegido, Héracles, uma linda flor, sobre a face pintada em estilo de figuras vermelhas de uma ânfora do Pintor de Andokidès (figura 8). ${ }^{31} \mathrm{O}$ herói aparece em um banquete, coroado e luxuosamente vestido, partilhando finalmente dos mesmos prazeres que os imortais, recompensa de sua longa trajetória heróica: a kliné suntuosamente decorada, a mesa cheia de alimentos, os dois vasos de beber e as vinhas se esparramando sob os pés de seus ramos de rica folhagem e grandes cachos espalhados em volta do herói como uma auréola, dando uma aparência desse estado de plenitude que somente os deuses conhecem. A flor oferecida com tanta ostentação pela deusa simboliza que Héracles agora é igual aos deuses; ela também é o símbolo daquela juventude perfeita e inalienável da qual o herói vai doravante desfrutar, juventude que também é encarnada por sua nova esposa, Hebe.

\footnotetext{
30Paris, Cabinet des Médailles 320; 520-510 a.C: ABV 389; Para 171; Add²102; BArch 302907. ${ }^{31}$ Munich, Antikensammlung 2301; 520-515 a.C.; ABV 255.4; ARV2 4.9, 1617; Para 113, 320; Add $^{2}$ 66, 149; BArch 200009. O gesto de Athená lembra muito aquele de Leda sobre a ânfora de Exéquias, figura 1. Sobre a face de figuras negras, atribuídas ao Pintor de Lisipides, Athená seguida por Hermes faz um gesto de saudação para Héracles em um banquete, o que demonstra que os dois gestos, com ou sem flor, são mais ou menos homólogos. Sobre o encontro de Héracles e Athená, ver Verbanck-Piérard (2006, p.133-151)..
} 


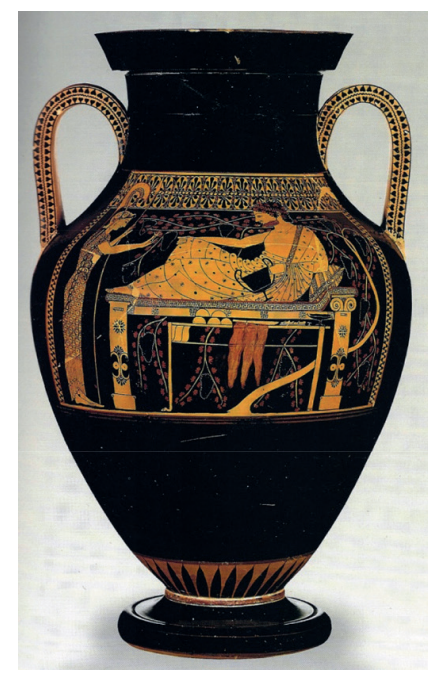

Figura 8

\section{A flor oferecida com tanta ostentação pela deusa simboliza que Héracles agora é igual aos deuses}

Ainda sobre o mesmo tema, um vaso grego atribuído ao oleiro Nicosthénès (figura 9), representa Héracles ladeado por Hermes e Athená: ${ }^{32}$ Hermes, que assegura a passagem do herói do mundo dos mortais ao dos deuses, o saúda com um gesto, enquanto Athená lhe estende um caule de flor, como sinal de acolhida. Em resposta, Héracles estende sua mão esquerda para aceitá-lo. Já em um lécito em Copenhague, ao contrário, é Héracles que estende uma flor a Athená, na presença de Hermes e Iolaos. ${ }^{33}$

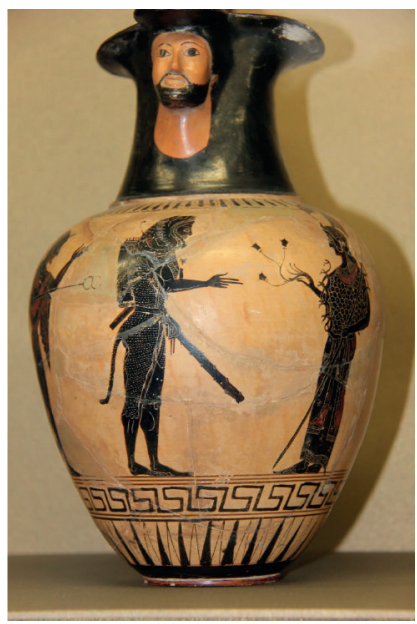

Figura 9 
A afinidade entre Athená e Héracles é representada de uma maneira mais evidente em um vaso grego do Pintor de Gela, no qual a flor não é mais estendida em um gesto, mas aparece bem destacada (figura 10). ${ }^{34}$ Vemos o héroi segurando com sua mão direita o punho da mão direita da deusa. Esse gesto, acompanhado de uma troca de olhares, é representado aqui como sinal exterior de uma relação de confiança mútua e de afetividade recíproca, ou seja, de philia. O pintor conscientemente marcou essa relação por um longo caule, que dá origem a uma bela palmeira, idêntica à da pintura, ${ }^{35}$ para melhor intensificar a familiaridade afetuosa das duas figuras. ${ }^{36}$

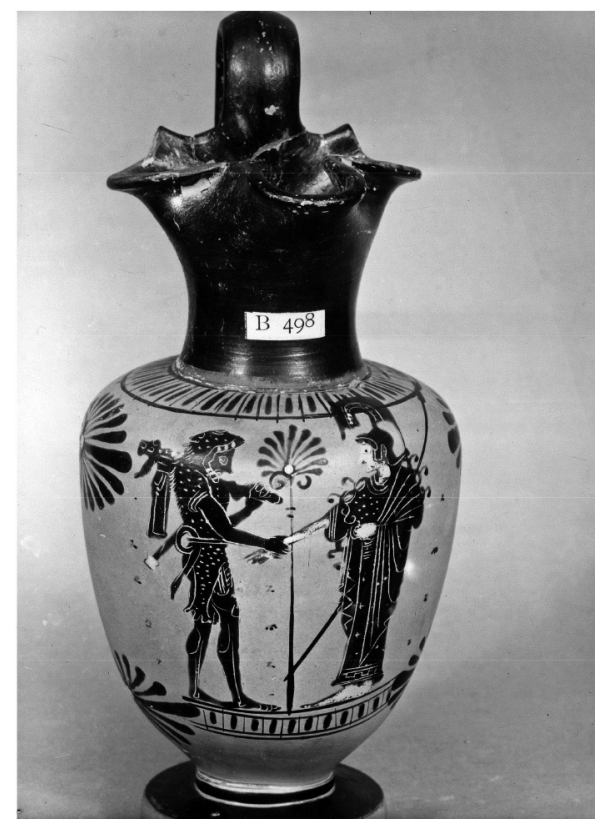

Figura 10

Essa imagem é bem próxima de outra do mesmo pintor, ornando um lécito em que Héracles e Athená, vistos somente em forma de bustos, trocam olhares. ${ }^{37}$ Esse tête-à-tête é celebrado por uma Niké alada, deusa da vitória, que, com uma coroa na mão, sobrevoa por entre os dois amigos. Logo abaixo dessa coroa e à meia distância do herói e da deusa, um caule de três brotos com folhas de palmeira forma um tipo de cruz, que reforça a relação interativa entre esses três personagens. À direita de Athená, uma figura feminina, igualmente

\footnotetext{
${ }^{34}$ Londres, British Museum B 498; por volta de 500 a.C.; BArch 31867; LIMC V, "Herakles”, n. 3184, pl. 142. Para uma história sobre o confronto entre Atena e Héracles ver Mommsen (1989, p.118-45).

${ }^{35}$ Note que, uma vez inserida na cena e em interação com as figuras, os motivos florais funcionam tanto como ornamentos, agentes figurativos e até como símbolo integral.

${ }^{36}$ Verbanck-Piérard (2006, p.137). Segundo a autora, o gesto figurado na oenochoé não é um dexiosis, mas um cheir' epi karpô, gesto que seria aqui, sem dúvida, representado sem suas conotações nupciais. Nos vasos áticos, representando o gesto de dexiosis entre Athená e Héracles, às vezes associado a um altar e aos utensílios de libação, ver LIMC V. s. v. “Herakles”, p.150.

37Vienne, Kunsthistorisches Museum 84; por volta de 500 a.C.; BArch 517; LIMC V, “Herakles”, n. 3129; Thomsen (2011, p.165-168).
} 
representada por um busto, é coroada por uma segunda Niké. Podemos pensar que se trata de Hebe, que os deuses, aqui representados por Athená, ofereceram como esposa a Héracles, uma vez que ele fora aceito entre eles. Uma vez esposa e encarnação da juventude eterna, Hebe é duplamente um dom de acolhida para Héracles, um lembrete de seu novo status de deus. Caso seja correta essa interpretação, teríamos uma imagem evocando as duas formas de philia, entre a deusa (e, por extensão, os deuses) e o heroi e aquela entre este último e sua nova esposa.

O mais belo exemplo de philia selada por uma flor é incontestavelmente o medalhão de uma taça de Douris (figura 11$).{ }^{38}$ A cena lembra muito aquela que orna a oenochoé do Pintor de Gela (figura 10). Hera entronizada, exibindo um cetro na mão, estende uma phiale para Prometeu, com o ar de um deus; envolto em seu himation, ele segura um tipo de coroa metálica e um cetro. Entre os dois, há todo um conjunto de linhas oblíquas. Inicialmente, a phiale aparece no centro da imagem e, mais precisamente, no ponto em que se entrecruzam o cetro da deusa e o de Titan. ${ }^{39}$ Depois, sobre a phiale, mas sempre no centro da imagem, aparecem dois enormes caules floridos do tipo ornamental, que Hera segura na mesma mão que seu cetro; suas flores chamam a atenção do espectador sobre os rostos das duas figuras, como se as ampliassem. Semelhante à imagem das mãos juntas representada na oenochoé do Pintor de Gela, esse jogo de quiasmos, de entrecruzamentos simétricos, evoca a natureza da ligação doravante igualitária entre Hera e Prometeu: nesse espaço que se fecha em torno deles, a deusa, que representa os deuses olímpicos, e o ladrão do fogo finalmente se reconciliam. A phiale evoca o ato de libação, bênção, e os dois caules floridos são as marcas externas dessa reconciliação.

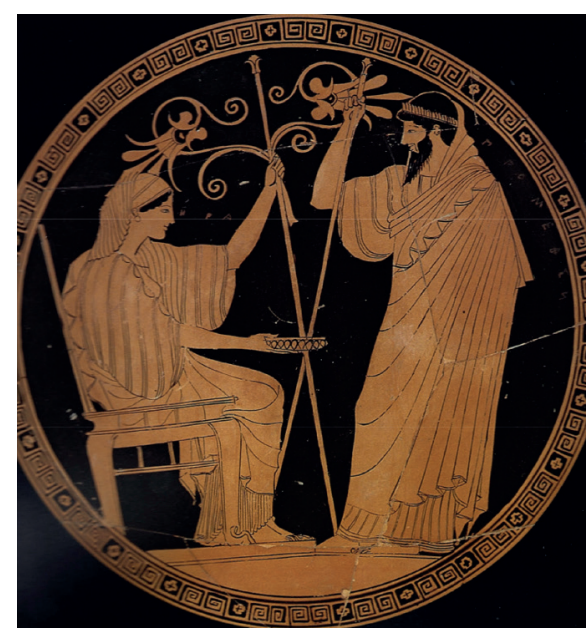

Figura 11

${ }^{38}$ Paris, Cabinet des Médailles 542; por volta de 480 a.C.; ARV² 438.133, 1653; Para 375; Add² 239; BArch 205179 ${ }^{39}$ Como observa Lissarrague (1999, p.145-6), há uma inversão de papéis nessa imagem, uma vez que, regra geral, é o homem quem está no troco e segura a phiale, enquanto a mulher o serve. 
Concluindo, a flor é um símbolo polissêmico, assim como os gestos que a envolvem. Ao longo deste breve estudo, interessei-me pela flor que é segurada em gestos solenes de saudação, de reconhecimento e até de reconciliação. Gestos que são finos e moderados, geralmente diferentes de gestos de simples demonstração. Contudo, esses gestos chegam a sugerir certa tensão, certa dinâmica entre o emissor e o destinatário da flor. Tal dinâmica se encontra sempre acompanhada de uma troca de olhares e, muito provavelmente, de uma troca de palavras, esses sendo os símbolos da vontade de se honrar reciprocamente, mas também como testemunhos da aliança, da estima e até do afeto entre pais, amigos e iguais. Em certos casos, a flor, quando não apresentada por meio de um gesto, fica na lógica do dom, da philia e da charis: como item ornamental, ela é um verdadeiro símbolo que põe em evidência toda a sua importância.

\section{Referências bibliográficas:}

ALAUX, Jean. Le liège et le filet. Filiation et lien familial dans la tragédie athénienne du Ve siècle av. J.-C. Paris: Belin, 1995.

AZOULAY, Vincent. Xénophon et les grâces du pouvoir. De la charis au charisme. Paris: Publications de la Sorbonne, 2004.

BENVENISTE, Émile. Le vocabulaire des institutions indo-européennes. Vol. 1, Paris: Éditions de Minuit, 1969.

BENVENISTE, Émile. Don et échange dans le vocabulaire indo-européen. In: Problèmes de linguistique générale. Vol. 1, Paris: Gallimard, 1982.

BRILLANTE, Carlo. Charis, bia e il tema della reciprocità amorosa. QUCC 59, 1998.

HERMARY, Antoine. Images de l'apothéose des Dioscures, BCH 102, Paris, 1978.

JAILLARD, Dominique. Configurations d'Hermès. Une théogonie hermaïque, Kernos, Suppl. 17, Liège, 2007.

KEI, Nikolina. La fleur: signe de grâce dans la céramique attique, Images revues, $\mathrm{n}^{\circ} 4,2007$ (online). KEI, Nikolina. La fleur: un signe de parfum dans la céramique attique. In: BODIOU, Lydie, MEHL, Véronique e FRÈRE, Dominique (eds.). Parfums et odeurs dans l'Antiquité. Rennes: Presses Universitaires de Rennes, 2008, p.197-203.

KEI, Nikolina. L'esthétique des fleurs: kosmos, poikilia et charis dans la céramique attique du VI et $V^{e}$ siècle av. J.-C. Tese de doutorado, 2010.

KEI, Nikolina. The floral aesthetics of attic red-figured pottery: visual adornment and interplay between ornament and figure. CVA, Österreich, Beiheft 2, no prelo.

LAURENCE, Kahn. Hermès passe ou les ambiguïtés de la communication. Paris: F. Maspero, 1978. LISSARRAGUE, François. Vases grecs. Les Athéniens et leurs images. Paris: Hazan, 1999.

MACKAY, E. Anne. Tradition and originality: a study of Exekias. Oxford: Archaeopress, 2010.

MACLACHLAN, Bonnie. The age of grace: charis in early Greek poetry. Princeton: Princeton University Press, 1993.

MOMMSEN Heide. Zwei schwarzfigurige Amphoren aus Athen, $A K 32,1989$.

SAINTILLAN, Daniel. Les “Grâces" des Grecs et la philosophie: de Platon à Hegel, Études Philosophiques. Vol. 4, n. 67, p.541-64, 2003.

SCHEID, Évelyne. Les usages du don chez Homère. Vocabulaire et pratiques. Nancy: Presses Universitaires de Nancy, 1994. 
SCHNAPP, Alain. Le chasseur et la cité. Chasse et érotique dans la Grèce ancienne. Paris: Albin Michel, 1997.

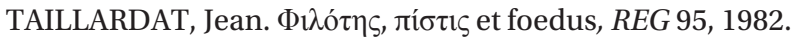

THOMSEN, Arne. Die Wirkung der Götter: Bilder mit Flügelfiguren auf griechischen Vasen des 6. und 5. Jahrhunderts v. Chr. Berlin /Boston: De Gruyter, 2011.

VERBANCK-PIÉRARD, Annie. La rencontre d'Héraclès et d'Athéna ou le regard des dieux. In: BODIOU, Lydie, MEHL, Véronique e FRÈRE, Dominique (eds.). L'expression des corps. Gestes, attitudes, regards dans l'iconographie antique. Rennes: Presses Universitaires de Rennes, 2006. VIDAL, Denis. Les trois Grâces ou l'allégorie du Don. Contribution à l'histoire d'une idée en anthropologie, Gradhiva, 9, p.30-47, 1991. 